\title{
ELEMENTS OF ISLAMIC ARCHITECTURAL HERITAGE: MINARET
}

\author{
SAHAR DIAB \\ KREBEEC, Ras al Khaimah, United Arab Emirates
}

\begin{abstract}
The minaret is an architectural "authentic" feature, which appeared as a landmark of Islamic cities. It used to be the place where the call to prayer is sent out, "Al Athan". However, maintaining using the same old-traditional language in designing and formulating the minaret, in a way that diminishes its visual power and eliminates it from the urban context by ignoring contemporary technological advances and capacities, has created an urgent need for reconsideration in minaret design. Hence, this research presents the important role of minaret as a distinct element of Islamic heritage and tries to redefine it in a modern perspective. This research defines its framework in three-dimensional aspects: form, function and content. This study attempts to determine the feasibility and applicability of contemporary implementations by reviewing and analysing a number of modern architectural projects and highlighting the challenges and difficulties facing the moderate application and new thinking in minaret element design. The research finds that contemporary technology and modern construction methods have offered various possibilities, forms and materials that could benefit and re-introduce the minaret as an element of the modern urban fabric too. Moreover, the role of the minaret could be activated in an unconventional way, which allows it to integrate and interact with its surrounding space rather than remaining a symbol from the past. In addition, this paper suggests the possibility of using the minaret element to achieve green objectives as an air trap, power generator and source of natural lighting. Keywords: minaret, contemporary architectural orientation, Islamic architectural, spiritual dimension, mosques.
\end{abstract}

\section{INTRODUCTION}

Islamic architecture emerges as a necessity that was able to emphasize the Islamic identity which had its own privacy and uniqueness [1]. The first mosques established during the era of the Holy Prophet Muhammad did not have a minaret element, especially "Quba Masjid" which was the first Islamic world mosque [2]. The Muslim architect innovated the minaret to raise the muezzin voice when he calling for Prayer over all other voices, and the tune of Allah is great becomes filling the ears along with the range over the long term [3]. By the time the minarets became one of the most important architectural terms that give the mosque its distinctive character, which was closely associated with the Islamic architecture, and the minaret become represents the most prominent feature of the mosque architecture. The minaret has gone through various phases of development and took various forms, from the simple minaret in the early Islam era to the complicated minaret form. This form was created by the mix of Arab architecture terms with the arts of architecture through ancient times which become an explicit expression of the fusion of the arts and was presented as the interaction of different cultures and environments under the banner of Islam. The minaret was introduced and developed as a symbolic function to show faith and an indicator of the presence of Islam. The construction of minarets has become the main element in mosque building in the Islamic world, and it signs as a feature in the city sky [4]. The minaret is the distinctive architectural feature of the mosque, which is principally used for the call to prayer (adhan) [5]. Currently, the minaret has lost its functional significance with the invention of loudspeakers. But people in the Islamic world cannot understand or accept the mosque without raise a minaret as a traditional symbol, identity and visual quality. With time, the 
minaret has become a fundamental part of the mosque such that it would be difficult to reach and know a mosque without its presence [6]. The minaret has a spiritual and symbolic role as well as its guiding role to the mosque location which means it is must exist and required [7]. In this context, a minaret would be more meaningful if it could serve further practical purposes and has contemporary functions. Nowadays, the world has reached advanced stages of architectural technology in various construction methods and materials, which must be used in the construction of mosques, including minarets. As well as, the contemporary society requirements and the 21 st century human needs have differed, which necessitates providing a contemporary formulation of minarets and mosques that highlight the time identity and harmony with the contemporary urban fabric, which restores the mosques' architecture content not only as of the place of worship but also as a source of cultural radiance.

\subsection{The importance of the research}

The importance of the research is to reveal the success of the contemporary minarets the formulation in the modern mosque buildings through its analysis within its three dimensions: form, function and content, also how to employ modern design techniques and new technology in minaret design. As well as the attempt to monitor the limitations behind the difficulty of activating the minaret inconsistent with the modern design trends in order to come out with results that contribute to highlighting the minaret as an element that has its significance and symbolism by using contemporary developments.

\subsection{Research approach}

The method of the paper is basically a descriptive analytical. The theoretical framework of the research depends on the presentation of the minaret concept and the factors that formed its appearance in the mosques. Also, the research based on followed other methodologies which are direct observation and field visits to some mosques in Jordan and UAE.

The selected case studies for ten mosques which are built-in modern times are the most innovative design which avoids the direct imitation of the inherited concept of minaret element design in traditional time in its form, function and content. The selection of these ten case studies is to shed light on the significant mosque examples in contemporary architecture by analysing the minaret element.

\section{THE FAMOUS ARCHITECTURAL PATTERNS OF TRADITIONAL MINARETS}

The minaret starts to appear as a part of the mosque's architecture in the Umayyad era in the eighth century. The Great Mosque in Damascus was the first mosque built with minaret and by the time the minaret comes into an essential feature of the mosque in all Islamic worlds [6]. The four towers, called the Sawāmi, constructed on the roof of the Umayyad mosque in Fustat and it was a separate structure from the mosque until the eleventh century. After that, the minaret became a main part and symbol of a mosque, as well as its function as a feature to guide traveling convoys [7]. The oldest pattern of the minarets was constructed in the Levant (Sham), where they were square towers form. This pattern was transferred to North Africa and other Islamic countries. Cairo is considered a minarets museum for various forms [1]. Some of the historians think that the first minarets, which were built within the mosques, are an advanced and developed form of the Iraqi ziggurats (Temples/Silo), in which the Muslim engineers found what fits the transition from physical to spiritual concept. Under the Islam growing expansion towards the east and west, the mosques patterned with minarets were spread, and the minarets forms were developed and its patterns were varied from one 
region to another and from one age to another, over the centuries, where the Islamic architectures arts were flourished. Every region developed its own signature styles. The minaret structures were influenced by the region's society, culture and context which determined their shape surface and colour [8].

In general, the completed constructed minaret consists of several parts [9] as follows:

- The minaret base.

- Staircase or ladder: often takes an internal spiral form, revolving around the minaret axis, with small windows for lighting and ventilation.

- The balcony (Al-Shorfa): the place where the Muezzin ascends to call for (adhan). The balcony usually takes the body's rotation, so that the Muezzin can mention (adhan) from all sides.

- Al-Jusaq: the upper part of the minaret.

- Crescent: the motto of Muslims, which is a shiny yellow metal, or a shining gold, installed at the top of the minaret.

It is possible to classify the historical minarets, in terms of the most famous architectural styles, as follows:

- The Umayyad style: considered the oldest style. One of its most important features of it are the base takes a form which is closer to the quadrilateral ribs, a huge structure, thick walls and various balconies, which the muezzin ascends to [10].

- The Abbasid style: the most affected by the ancient the architecture of the Mesopotamian civilization, especially the ziggurats architecture, which is characterized by circular cylindrical projections, limited balcony, the height increases and smooth surfaces in the exterior with decorations and miniatures.

- Persian style: the most prominent features are that it contains the pointed arches for decorative, or structural purpose [11], in addition, it has various types of decoration and sculptures.

- The Egyptian style: distinctive features emerged during the Fatimid period and was developed in the Ayyubid and Mamluk periods. The most a prominent characteristic of these style minarets is the various ribs, which take a hexagonal or octagonal form [11], and it often takes the form of the small chair which is based on marble pillars.

- The Indian style: characterized by the polygon body, whose ribs look like close and adjacent pillars, with various balconies, and they often adorned with muqarnas [12].

- The Ottoman-style: the most significant of these is height, which is more than 50 meters in many minarets, as well as the pointed shape covered with a lead plate, which ends with the upper balcony, and takes the body of the arrow going towards the sky.

- A special style, known as the twisted [11], which is semi-conical, and the ladder runs around its full body from the outside.

\section{THE DIALECTICAL, PHILOSOPHY AND THE SYMBOLIC CONNOTATIONS OF THE MINARET}

The Muslim architect was interested in the minaret design and its engineering which had given it a spiritual dimension, characterized by the high originality. The Muslim architect took upon himself the necessity to develop the minarets' form through the appropriate technical and engineering improvements. This development has fit the self-transcendence concept to the spacious heaven through a visual vision that the architect wanted for the viewer 
from the bottom of the minaret to the top [13]. This concept is a clear expression that the minaret is represented as a transit point for the departure from the earthly reality to heaven. This concept has been confirmed in the design by the minimized the effect of the basic building material from the bottom of the minaret until the higher of it. And to achieve the wanted effect in the viewer spirit, the architect used the brick stones in the minaret bottom and the smooth ratios and accurate decorations in the minaret top in the hierarchy sequence [11]. The understanding of connotation and symbolism of minarets required an aware philosophical reading of the idea of the symbol in Islamic architecture and the associated significances of the used form.

With regard to minarets, the writer, Grabar, writes in his article "Symbols and Sign in Islamic Architecture": the minaret has an Islamic symbolism and it has significances for a product or a cultural identity. In his interpretation of the symbol, as stated in his article, the symbol has variable qualities and characteristics [14]. Dr Walid Al-Sayed thinks that the "Grabar" involvement is not enough to understand the dialectical relationship between the symbol and the function, especially when the function is variable or subject to continuous modulation processes, as the minarets case including its contemporary function, which is not related to its historical function that was created for in the early of Islam.

Dr Walid Al-Sayed believes that the triple relationship between form, function and content defines the form symbolism of the Islamic architecture - for example the minaret. He adds that it is wrong to attribute the form to a culture or identity, but the form significance is determined by its relation to the triple system within its cultural framework, which gives the form its symbolism and authority/reference to this culture or that. In conclusion, the view of Dr Walid Al-Sayed is it necessary to keep away from the usual form content of mosques' architecture - including the minarets - which its need re-considering and presenting it in a harmonious method with the surrounding urban fabric. This requires providing modern ideas for mosques' architecture, which are must integrated with the surrounding environment and the concepts of contemporary lifestyles [15].

As for Jonathan Bloom's view, through the interview conducted with him by Geoffrey Ern regarding the importance and significance of the minarets [16], he said that the first minarets were not built for the call of prayer purpose. Therefore, he mentioned that the minaret function was since then and has not been changed until today, that is, it was a symbol of the mosque position, therefore a symbol of Islam. The minarets did not become a place where to call for prayers until at the later time. Bloom continues his interview "the minaret like the dome above the mosque is considered one of the distinctive terms of the Islamic architecture", he said.

Today, the minarets have become one of the Islamic symbols without any ambiguity. Bloom indicates the minaret symbolism historically, where after the Ottoman Sultan Mohamed Al-Fateh had occupied the Constantinople Byzantine city in May 1453; his first act was to order the construction of a wooden minaret on the 900 -year-old cathedral of Hagia Sophia. His purpose was to show that it was converted into a mosque apparently. When Mohamed Al-Fateh and his successors had built other mosques, the public scene in Istanbul was gradually filled with dozens of minarets that took the shape of a thin, sculptured and carved column. That also symbolized that Istanbul was no longer become the capital of the Byzantine Christian state, but the new capital of the international Islamic caliphate. He concluded his speech that although the minaret is not one of the necessary components of the mosque as asserted by the Swiss Max van Persheim - a researcher in the Arabic literature field - but the minaret is considered as an important element to build. The minaret remains a powerful symbol of Islam, and accordingly, it has been repeatedly placed in the middle of the scene. Bloom's conclusion put us forward to the fact that, unlike other architectural 
features of Islamic history, the minaret stands for a clear affiliation and function. It is the symbol of Islam, but this symbol is not unified in one form. Through Islamic history and its geographical extension, the architectural forms of the minaret have changed and varied.

In his lecture entitled "The minaret, a symbol of civilization", Sharif Shah Abdul Rahman, the head of the Islamic Culture Organization in Spain, thinks that the importance of the minaret rises from being a symbol of the Muslim community centre, which calls from the top, in reference to trends to Allah. And he sees that the western researchers have their own background that enables them to discuss the "power" and "domination" the meaning of the minaret. Also, minaret's significance has become a symbol of the spread and presence of Islam around the world. His thought conclusion is that once we see a high-rise minaret in the sky of a city, we immediately know that we are in an Islamic city or a place inhabited by Muslims, and once we see the minaret portrait in the paintings so the identity of the artwork is immediately known [17].

\section{CASE STUDIES: THE USE OF FEATURES AND THE CONTEMPORARY ARCHITECTURE TECHNOLOGY EXPERIMENTS IN THE FORMATION AND RECONSTRUCTION OF MINARETS}

\subsection{Case 1: Al-Humshari Mosque; Location: Jordan, Amman - Khalda; Designer: Atelier White, Dubai; Completed in 2011}

The minaret located towards the concave (mihrab) and it is separate from the mosque mass. The minaret design matching the contemporary design features. The white stone and marble were used for the construction. Its form is a simple square-shaped minaret and has been adorned with embosses with Arabic abstract lines and an iron crescent-shaped with a contemporary display.

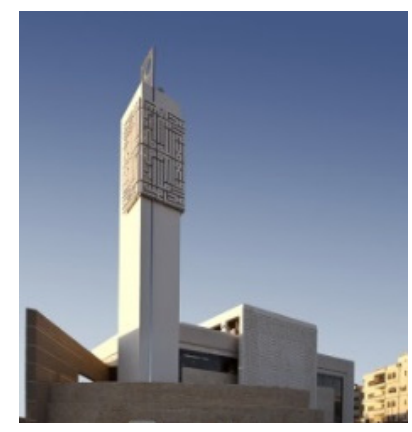

Figure 1: Minaret at Al-Humashri Mosque, Amman. (Source: The author, 2016.)

\subsection{Case 2: The Dead Sea Mosque (not constructed); Location: Jordan, the Dead Sea;} Designer: Architect Dr Farouk Yaghmour

The mosque is located on a high hill. The minaret's exterior appeared in contemporary features and modern building materials. Yaghmour did not only give the minaret a contemporary design characteristic in its form, but he also added a modern functional dimension with a panoramic elevator inside the minaret. The elevator direction and view at the end was towards Jerusalem. During an interview with Dr Yaghmour, he mentioned the 
importance of Jerusalem and Al-Aqsa for Muslims, as well as the importance of the visual and spiritual communication felt by ascending to the top of the minaret, thus a high vitality and spirituality are given to the mosque. The project could not become a tangible reality, due to financial and political reasons, but it remains the first intellectual and spiritual approach to the development of a contemporary design of the minaret in Jordan.

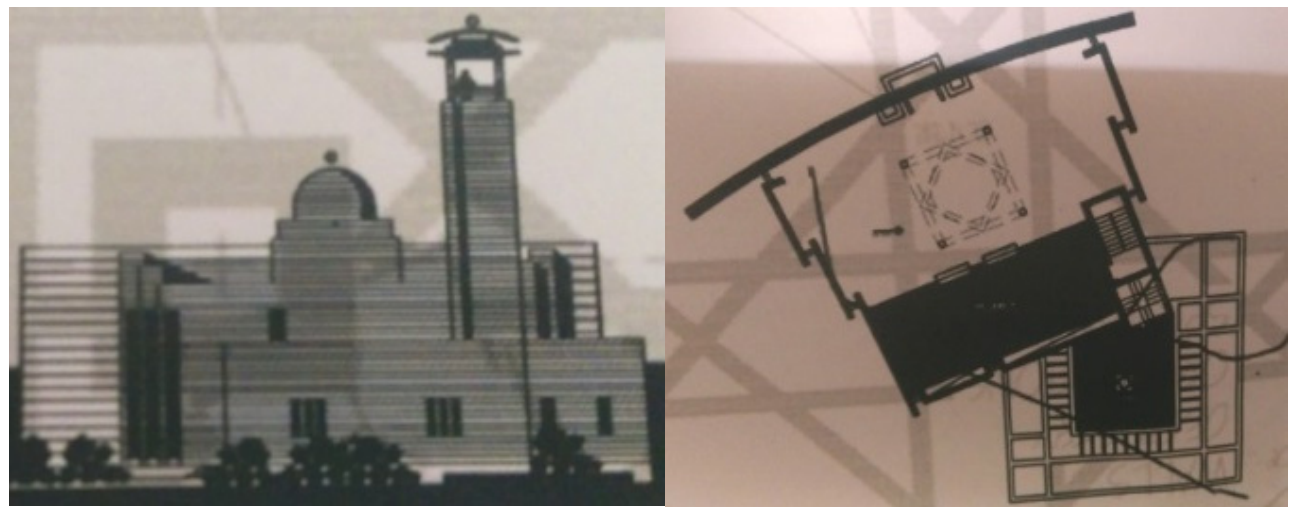

Figure 2: Main elevation and plan of Dead Sea Mosque. (Source: Designer, 2016.)

4.3 Case 3: Ahl Al-Qur'an Mosque; Location: Ramtha; Designer: Eng. Wael Al-Masri; Planners and architects

The square-shaped minaret is constructed next to the mosque. It is extended to more than $30 \mathrm{~m}$ high. As well as, it is illuminated in a creative way which gives the minaret and the mosque the modern Islamic architecture character, and also gives the mosque a kind of luxury and elegancy by its stone building and colours overlapping with the metal crescent, which are risen on its top.

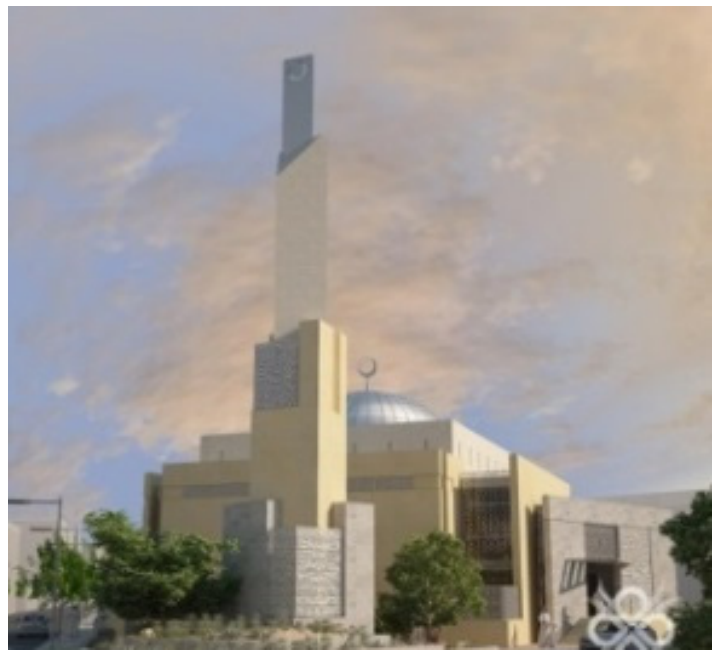

Figure 3: Perspective of Ahl Al-Qur'an Mosque. (Source: www.waelalmasri.com.) 
4.4 Case 4: Al-Musharaf Mosque; Location: Abu Dhabi, United Arab Emirates; Designer: Al-Ain Office for Engineering Consultants

The minaret of Al-Musharaf's Mosque is characterized by its towering height (40m). It stands as a completely separated element from the mosque on the right side of the main prayer Hall. The minaret took the rhombus shape and it was characterized by two glazed angles which were covered with GRC Islamic embosses and ended with a bevelled surface on which the crescent hung. The glazed area is illuminated by green colour.

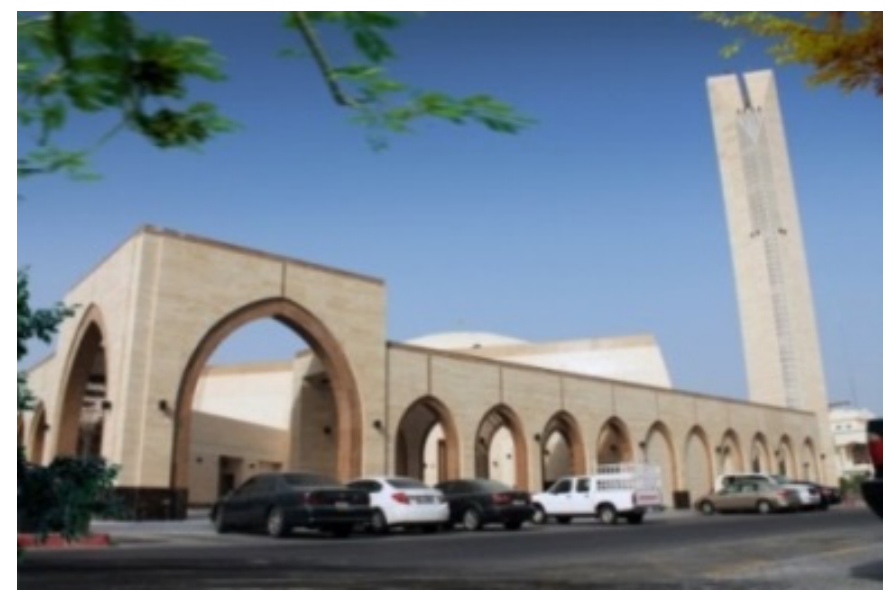

Figure 4: Al-Musharaf Mosque, Abu Dhabi. (Source: Author, 2016.)

\subsection{Case 5: Al-Aziz Mosque; Location: Al-Reem Island, Abu Dhabi, UA; Designer: APG}

The minaret represents a vertical element separated from the mosque by a high altitude. The minaret was characterized by the advanced technology used in operation, and illuminate the minaret at night, where the fibre optics used for lighting.

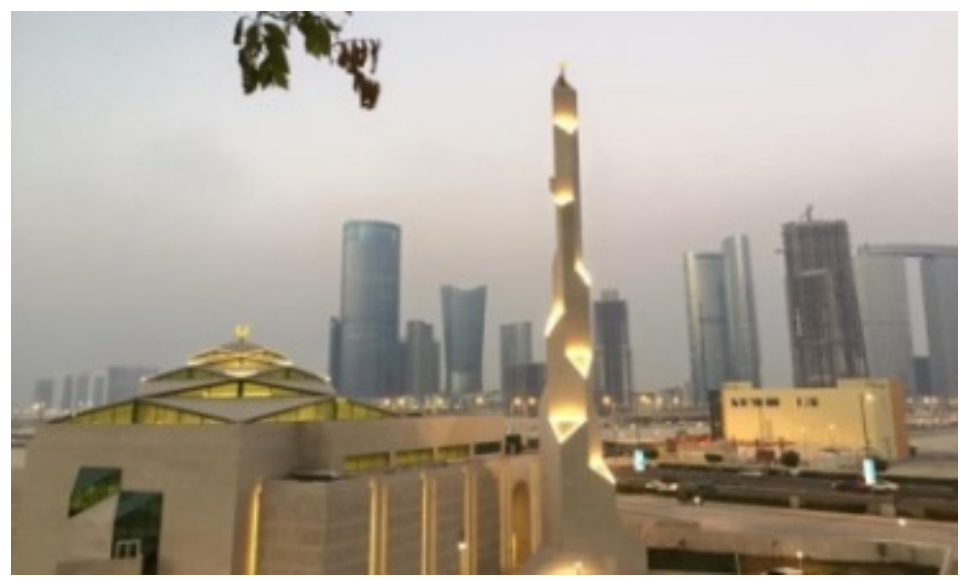

Figure 5: Al-Aziz Mosque, Abu Dhabi. (Source: Author, 2016.) 
4.6 Case 6: Eco-friendly mosque planned for Germany; Location: Hamburg, Germany; Architect: Selcuk Ünyilmaz

The mosque contains two minarets that functionally symbolize the identity of the mosque and Islam in an innovative modern design. The architect wanted to give the minarets a contemporary function. The wind turbines will be housed in the two minarets at 22-metrehigh and Ünyilmaz plans to install a pair of 1.5 -meter glass rotor blades in each tower. At certain times of the daylight will be beamed at the blades to create a kind of light show inside the mosque. The aim of turbines installation is to provide 30 percent of the mosque's energy needs and to recoup their cost within 10 years.

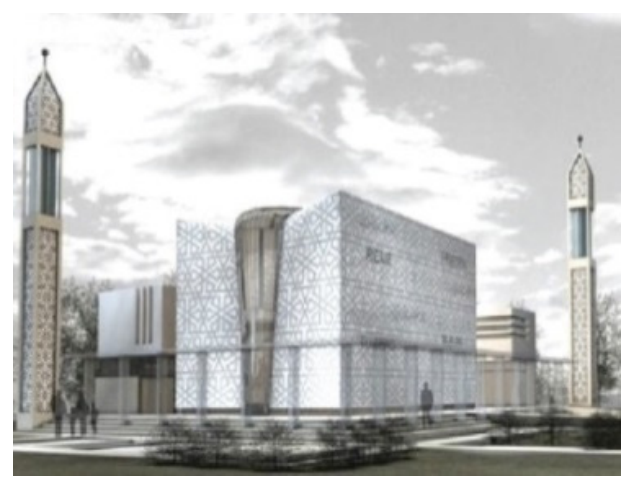

Figure 6: Modern environmental mosque. (Source: www.theecomuslim.com.)

\subsection{Case 7: Wesley Fadi Mosque in Turkey; Location: Turkey; Designer: the Turkish Architect, Adnan Kazmoglu, 2010}

Minaret positioned detached from the main structure of the mosque. It appears as a selfstanding, a vertical element, which has basically a symbolic function. What is innovative in its design is the integration of illumination to the main design of the minaret. Galvanized metal pipes are shaping the minaret balcony and they are also hiding the light sources and the loudspeakers. As a very innovative function, the minaret is also serving as a sundial. By its shadow falling onto the markings inscribed to the ground of the main piazza to show the time. In this mosque, the usage and interpretation of minarets have reached a high level.
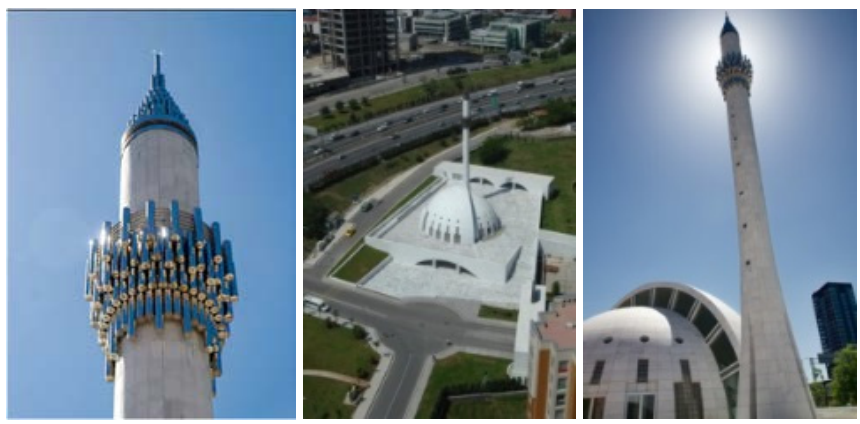

Figure 7: Wesley Fadi Mosque. (Source: abunawaf.com.) 
4.8 Case 8: Environmentally friendly Mosque in Turkey; Location: Turkey, Bursa; Designer: Glick Iringazgine

The mosque produces its own energy and even sells the surplus. Electricity will be generated from the pressure of worshipers on the floor. As well as, the mosque will use its own solar energy and wind power to produce electricity. The shape of the two minarets is similar to that of the Ottoman minarets in its thin tall, finely shaped structure and its tapered ends. However, the addition is that there is an air trap on each of the minarets, allowing the operation of turbines that generate electricity.

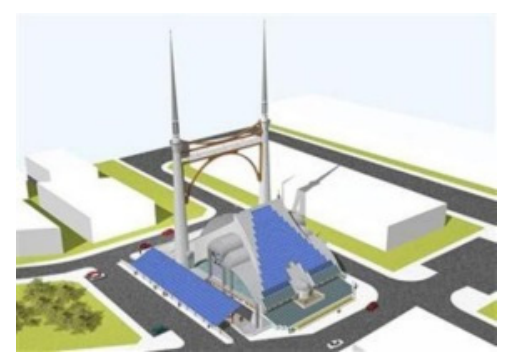

Figure 8: Environmentally friendly mosque, Turkey. (Source: www.altawhid.or.)

\subsection{Case 9: Abdul Rahman Siddiq Mosque; Location: Palm Island, Dubai; Designer: Architect Dr Farouk Yaghmour}

The architect used the idea of the pattern in this design, which characterized the old local architecture in Emirates and he wonderfully shaped it on the front of the Qibla. The minaret also simulates the principle of the three layers of stones on the main elevation. It was not only an aesthetic block, but he restored its functional status by designing it in a panoramic style, with a panoramic elevator, through which the user can climb up and see a view that shows the palm island. The panoramic elevator idea is not approved by the Donor Authority (the client), as well as the Ministry of Endowments has not implemented it.

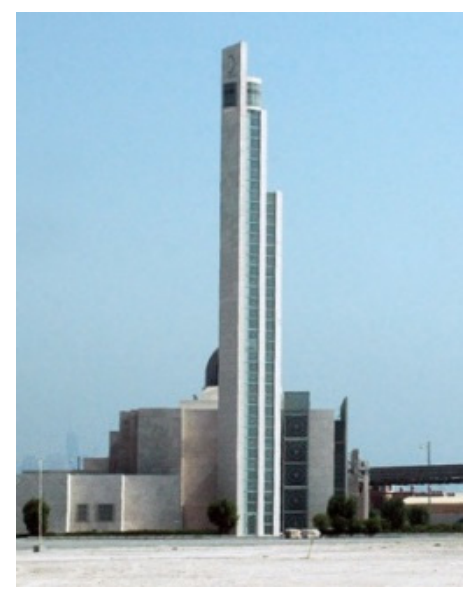

Figure 9: Abdul Rahman Siddiq Mosque. (Source; Designer, 2016.) 
4.10 Case 10: Grand Mosque of Algeria; Location: Algeria, Mohamedia District; Designer: KSP German Architects

The minaret was designed to be the world's tallest minaret of 265 meters and is known as the dynamic minaret because it represents a unique case and the first of its kind situation in the Muslim world, in terms of form, content and function. The entrance to the minaret is located in a large lobby facing the adjacent U-shaped building. The minaret is divided into many architectural spaces that are accessible through a panoramic elevator. In terms of the form, it was designed squarely, where the stones and the semi-translucent glass were used to cover the minaret from the outside to appear in a contemporary style. In terms of the function and content: the minaret includes a number of communities and educational spaces before reaching the last platform, where the visitor can see a unique view of the surrounding areas rich with the Islamic historical houses and buildings. The minaret's first floors are occupied by the public areas, terraces and gardens for visitors and topped by the Islamic history museum which is opened to the public. The Islamic research centre for academics only, the library and a learning centre for teaching Quran is located above it. The minaret emerged as an integrated interactive component with society's requirements.

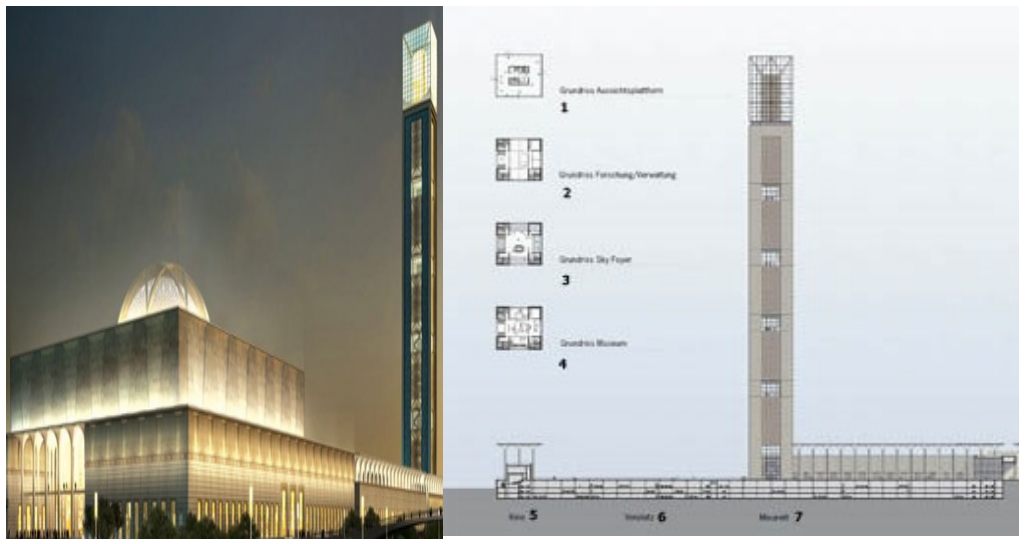

Figure 10: Grand Mosque of Algeria, Algeria. (Source: www.kuk.de.)

\section{RESULTS AND DISCUSSION}

1. Extend the lessons learned from the minaret formation and functions as stated in many of the examples reviewed by this research in order to determine the minaret formulation in an integrative element and not merely formative form suitable for the contemporary time and place.

2. It is possible to choose non-traditional forms, modern building materials and enormous heights that create from the minaret an element that simulates the contemporary urban fabric as in many of the cases reviewed by the research.

3. There is a possibility of activating the minaret role by non-traditional joint activities that create an interactive and complementary place with the surrounding environment rather than just having a minaret as a symbolic significance of the mosque or the Islamic community as shown in the experience of the Grand Mosque in Algeria. 
4. The case studies analysis find that the contemporary architectural orientation towards sustainable architecture and environmentally friendly buildings have had a clear impact on the mosques of Turkey and the West, where the minarets have been used as high vertical elements as air trap, running wind turbines and assembling natural lighting.

5. The possibility of employing and exploiting modern technology in adding a deep the spiritual dimension of the minaret as attempts of Dr Yaghmour to add a panoramic elevator in the Dead Sea Mosque (not implemented) and its visual connection with Jerusalem (the first Muslim Qibla).

6. The need for continuity presenting the bold models of the designs of the mosque and give them its real content functionally and not only in the form until we get to the desired awareness in the mosques' contemporary architecture.

7. By the case studies analysis in this research, we can find that the architect should respect the contemporary time and the modern technology to offer the theses of the mosques that keep pace with the age and the contemporary urban fabric, not just by form but also by a strong content.

8. Creating a new function for the minaret to give it a contemporary formula compatible with contemporary technology, not in terms of the form and the materials used in the construction, but also in terms of the content. This addition launched because of the mosque was historically built not only as a place of worship but also as a cultural radiation centre.

\section{CONCLUSIONS}

1. The first obstacle that faces many contemporary architects is the superficial and abstract understanding of Islamic architecture, which caused the weak of modern mosques design models. The architects should understand and incorporate the traditional mosque architecture in its full form and content so that they can present a contemporary model of the mosque in the 21 st century, which stimulates the age requirements and implement the contemporary architectural architecture trends, as well as not deviate from the mosque contents as a place of worship and a source of the Islamic and civilizational radiation.

2. The use and employing the minaret in a modern manner should be regarded and not to be frozen it in its traditional form and its old function in an originality and modernity framework.

3. The social acceptance of using modern features ideas in the architecture of the mosques causes another obstacle because the image of the mosque is firmly rooted in the people's minds historically in a traditional style. It is necessary to provide bold models by the architects and this needs the long patience and argument until we reach the desired awareness of the mosques' contemporary architecture.

4. The modernization of the contemporary minaret and releasing it from its mindrooted the traditional form is not easy. That required the full knowledge, awareness and a deep understanding of the situation by the architect to make the new design of minaret element acceptable.

5. The inherited architectural concept should be employed in a contemporary manner through the appropriateness between the form, function and the content of the minaret to reflect the time, place and technology of the age.

6. The historical review of the architectural styles of the minarets reveals the identity of every Islamic civilization that has passed through history. This leads us to the 
need to re-activate the minaret element with its three dimensions in a way that highlights the advanced possibilities of science in the architecture technology field of our time.

7. The need to develop legislation in a way that facilitates and stimulates the move towards modernity and the use of modern technology of the age in the new feature formulation of the minaret architecture.

8. The decision-makers and the government authorities should cooperate with the designers to come up with a mature architectural form of the mosque architecture, including minarets, to emerge from its traditional framework and submit it in a way that highlights the contemporary identity.

\section{REFERENCES}

[1] Lutfi Abdul Amir, S., The aesthetic dimensions of the minaret in the Islamic architecture. Babylon University Magazine, 18, p. 2, 2010.

[2] Al-Balazari, A., Fattouh Al-Madinah, India, 2nd ed., p. 6, 1866.

[3] Sakhr, F., Introduction to the aesthetic in Islamic architecture. Arab Arts Magazine, 2, p. 5, 1982.

[4] Kenan, The vanishing mosque. Islamic Arts Magazine, 2010.

[5] Creswell, The Evolution of the Minaret with Special Reference to Egypt, 1926.

[6] Bloom, J. The minaret symbol of faith and power. Saoudi Aramco World, 53, 2002.

[7] Hoteit, A., Contemporary architectural trends and their impact on the symbolic and spiritual function of the mosque. International Journal of Current Research, 7(03), pp. 13547-13558, 2015

[8] Binti, W.A. \& Kamal, W.A., The Significance of the Minaret as the Symbol of the Official Religion, Universiti Teknologi MARA (UiTM): Shah Alam, Selangor.

[9] Abdel Hafez, H., Architecture of the minarets and the historical domes in the Grand mosques in Istanbul, Turkey. Al Guraba Magazine, no date.

[10] Al-Badawi, d.M.H., For the References in the Secrets of Minarets \& Lighthouses, 1st ed., Al-Wabel Alseeb for Production, Distribution \& Publishing, p. 23, 2008.

[11] Salem, d.A.N., The History of the Famous Mosques, p. 189, no date.

[12] Osman, d.M.A.F., Al-Shorouk Encyclopaedia, volume I, the Part of Colour Arts Mosques, Dar Al Shorouk: Cairo, p. 212, 1994.

[13] Hamouda, Y.M., The Architectural Formation, Dar Al Ma'aref: Cairo, p. 56, 1972.

[14] Grabar, O., Symbols and signs in Islamic architecture. Architecture and Community, ed. R. Holod \& D. Rastorfer, New York: Aperture, 1983.

[15] Ahmed, W., The crisis of the mosque architecture. Leonardo Journal, 1, p. 3, 2011.

[16] Bloom, J., Interview with Ern Geoffrichin.

[17] Ezzat, A., Reference to the heaven and proclamation of existence. Al-Shorouk Newspaper, 2009. 